\title{
New Remuneration System for Village Government Apparatus (APD): Can it Halt Fraud Incident(s)?
}

\author{
Mellani Yuliastina ${ }^{1}$, Muhammad Hudaya ${ }^{2}$, Wahyudin $\mathrm{Nor}^{3}$, and \\ Basyirah Ainun ${ }^{4}$
}

\begin{abstract}
:
Research aims: Central and local governments are trying to curbing fraud involving the village government apparatus (APD) by increasing the remuneration of APD, so that they are not tempted to misuse the village fund that they manage. Design/Methodology/Approach: The purpose of this study is to see whether remuneration is the cause of fraud, the extent to which the application of new PPE remuneration has an impact on reducing the potential for fraud and who is the main actor in fraud. This research uses a qualitative approach, and case study strategy research. The research was carried out in in three villages within a district, Regency of Barito Kuala, South Kalimantan. Data were collected through several relevant informants interviewed using the open-ended questions technique.

Research findings: The results of this study indicate that APD is required to be professional to carry out their duties in managing village development, but on the other hand, the compensation for workload received is not commensurate with the risks faced. However, the increase in remuneration for the APD is only happened to the village head and village secretary, while the head of affairs and head of section's renumeration remain below regional standard pay (UMR). The main cause of fraud is in the aspect of hegemony power and governance.

Theoretical contribution/ Originality: The new remuneration system is supposed to curb the potential fraud, however, it leaves new loopholes for committing fraud. The paper suggests the new renumeration system needs to be revamped, in which all APD should receive minimum pay at UMR level, Improved governance, encouraging community participation and eliminating stereotypes about power as an effort to achieve prosperity.

Research limitation/Implication: This research was conducted using a qualitative approach where the results of this study cannot be generalized to a wider scope. Keywords: Village Fund; Fraud; Apparatus Renumeration
\end{abstract}

\section{Introduction}

ARTICLE HISTORY

\section{Received:}

01 June 2020

Revised:

10 Sep 2020

05 Oct 2020

Accepted:

15 Oct 2020

Villages need to be developed to reduce the gap with cities by maximizing the potential management and characteristics of each area. Law Number 6 of 2014 mandates the central government to provide at least $10 \%$ of the State Budget as village funds. This law was made to align villages to become honourable subjects within the framework of the Indonesian constitution. 
The strengthening and manifestation of villages to become independent through laws place villages as the governance and development subject that departs from a bottomup position. After the distribution of funds to villages, many regions carried out the expansion, and several regions proposed a status change from "kelurahan" (urban village) to "desa" (village). These activities were carried out to acquire funds (Okezone News, 2017). In 2016, the number of villages increased from 74,093 in 2015 to 74,754. Furthermore, in 2017, there was an increase by 200 , thereby culminating in 74,954 with a budget allocation of 60 trillion rupiahs (DitjendPDT, 2017).

The quality and quantity associated with the roles and responsibilities accepted by the village have not been accompanied by adequate human resources (HR) due to inadequate broad authority and understanding related to the principles of funds selfmanagement (IP03;IP04, 2017). Furthermore, they do not have procedures, facilities, and infrastructure to support financial management both in terms of income and expenditure budgets (Sofyani, Suryanto, Wibowo, \& Widiastuti, 2018). APD has a high criminalization risk considering the number of funds that the government needs to manage. The rampant criminalization of village heads due to their ignorance and poor governance is one of their problems (Kompas, 2018; Republika, 2017).

Fraud is an act against the law, which is deliberately carried out by people inside or outside an organization for personal or group benefits, directly or indirectly harming other parties (Association of Certified Fraud Examiners, 2016). Examples of fraud include manipulation or giving statements, false reports against other parties, etc. This illegal activity is divided into corruption, asset misappropriation, and fraudulent statements, as shown in Figure 1. The tempo online news stated that the Marabahan District Attorney, Barito Kuala Regency, South Kalimantan, has conducted an investigation into corruption allegations in the village funds allocation at Pindahan Baru, Rantau Badauh Subdistrict. In 2015, the alleged corruption related to the construction of roads, village culverts, security posts, and procurement of bikro stones was worth 500 million rupiah (Tempo, 2016).

Furthermore, in 2017, the Village Head of Sungai Rasau, Cerbon Subdistrict, Barito Kuala Regency (Batola), had to face the law for alleged corruption in the Village Income and Expenditure Budget (APB) amounting to IDR 367,400,429 (Klikkalsel, 2019; Kumparan, 2018). This incident indicates the high risk faced by village fund managers and illustrates that there are 2 (two) types of management, namely becoming a resident of a "prodeo hotel" or being prosperous, with a questionable APD welfare. In early 2018, a petition was addressed to the President of Indonesia, driven by one of the APD that is also a member of the Indonesian Village Apparatus Association (PPDI) on the change.org website. The petition highlighted that the welfare in terms of remuneration, received by APD is not proportional to the job demands.

Welfare is a central issue associated with several success stories of village funds. According to studies, Switzerland has succeeded in becoming the third corrupt-free country after several decades due to the proper utilization of its welfare resources. The country was selected in-line with Finland with a score of 85 , followed by Denmark and 
New Zealand in second and first places with scores of 88 and 89, respectively (Transparency International, 2018). In the 17th and 18th centuries, Sweden was known as the most corrupt country in Europe, however after implementing an initial increase in remuneration of their civil servants, there was a balance with regulations, which turned the country into a corrupt-free nation within two decades (Kornai, Haggard, \& Kaufman, 2001).

The Corruption Eradication Commission (KPK) likens corruption in this country to a "forbidden inheritance" without wills. Furthermore, Syahroni, Maharso, and Sujarwadi, (2018) stated that corruption is a culture that tends to remain sustainable and preserved despite claims that it is forbidden by regulations in each ruling regime. Corruption affects every aspect of Indonesia's life due to internal and external factors. Some of the internal factors include weak faith, honesty, shame, corrupt attitudes, or behavior (Corruption Eradication Commission, 2015). External factors are determined from economic aspects such as inadequate income, political interests that lead to instability, and the process of gaining and maintaining power. This is in addition to the poor management and organizations due to the poor form of legislation, weak law enforcement, as well as social aspects such as the environment or society that does not support anti-corruption behavior (Komisi Pemberantasan Korupsi, 2015).

The basic idea that promotes the increasing wages policy as an effort to mitigate fraud comes from Becker and Stigler (1974), according to them, an increase in the civil servant's wages above the official salary, encourages them be honest. Van Rijckeghem and Weder, (2001) also stated that an increase in welfare (salary) has a significant effect in decreasing corruption. This assumption underlines the statement that high government official salaries reduce corruption (Lederman, Loayza, \& Soares, 2007; Liu \& Lin, 2012; Pellegrini, 2011). It also supports the research carried out by Tella and Schargrodsky (2014), which stated that there is a relationship between welfare and a decrease in corruption due to various conditions during auditing.

According to (Gong \& Wu, 2012) the low remuneration rate of government officials, with high service expectations, leads to an illegal and informal increase in corruption. The findings show no relationship between high government official salaries and a decrease in corruption (Gong \& Wu, 2012). This is in line with the research carried out by Abbink, (2002); Rauch and Evans, (2000); Treisman, (2000). Furthermore, there are still mixed studies related to remuneration, and some still show doubts, irrespective of their ability to explain the close relationship between welfare and fraud. The research associated with welfare/remuneration/salary is still limited, especially in the context of public sector institutions at the village government level. Oktavia, Sayekti, and Prasetyo (2018) research showed a negative effect on fraud compensation in Pasirian Subdistrict, Lumajang Regency. Therefore, based on the phenomenon related to the issue of welfare/remuneration/compensation and the large responsibility borne by the Village Government Apparatus (APD), research related to this topic becomes interesting to explore. Trompeter, Carpenter, Desai, Jones, and Riley Jr (2013) also suggested an understanding of compensation's role in relation to fraud mitigation. 
This study differs from Oktavia et al., (2018) research because it specifically examines the causes of fraud based on the fraud theory in accordance with Maslow's hierarchy of needs and hegemony. This research extracted direct information from informants on the tendency to commit fraud and the benefits of village funds related to remuneration issues for APD. Therefore, the research focuses on whether remuneration is the cause of fraud and how the implementation of new APD impacts reducing its potential and the main actor. According to Blackburn, Bose, and Haque (2011), economic pressures contribute to the occurrence of fraudulent behavior. Perpetrators of fraud perceive their wages to be incompatible with their work. Furthermore, bureaucrats with less wages expect to receive compensation through some form of malpractice (Blackburn et al., 2011).

The government has issued priority for the yearly utilization of village funds to minimize fraud. This program is achievable when all factors involved participate in building the village as a form of equitable development in accordance with Law No. 6, 2014, including the vital role of APD. The analysis results can be used for various decisionmakers to determine the risk and return conditions received by APD in managing village funds, and potential (loophole). This research is also expected to act as an additional literature review on the potential factors that lead to fraud, particularly in terms of the relationship with remuneration.

\section{Literature Review}

\section{Fraud}

According to Albrecht, Albrecht, Albrecht, and Zimbelman (2015):

\footnotetext{
"fraud is a generic term and embraces all the multifarious means which human can ingenuity devise. It is defined as the process adopted by an individual to get an advantage over another by false representations. No definite and invariable rule can be laid down as a general proposition in defining fraud, this is because it includes surprise, trickery, cunning, and unfair ways by which another is cheated. The only boundaries defining it are those which limit human knavery".
}

According to Tuanakotta, (2010), fraud includes various actions against the law, which can be overcome by prevention and detection. Several theories such as the CDMA developed by Klitgaard, the fraud triangle developed by Donald R Cressy, the willingness and opportunity for corruption, the perpetrator motivation, the cost-benefit model, and the gone theory put forward by Jack Bologne, stated that the causes of fraud are negligence, opportunity, rationalisation, and capability. Vousinas, (2019) developed a fraud hexagone which stated that collusion is another factor that causes fraud. Therefore, it becomes a stimulus, capability, collusion, opportunity, rationalization, and ego, abbreviated as S.C.C.O.R.E. The elements of hexagone fraud can also be used as an analytical tool to determine causes of fraud. Vousinas, (2019) stated that collusion can be used to determine the factors causing white-collar crimes such as fraud in the corruption section. 


\section{Types of Fraud}

Association of Certified Fraud Examiners (2016) schematically divides fraud as occupational in the form of a fraud tree, as shown in figure 1.

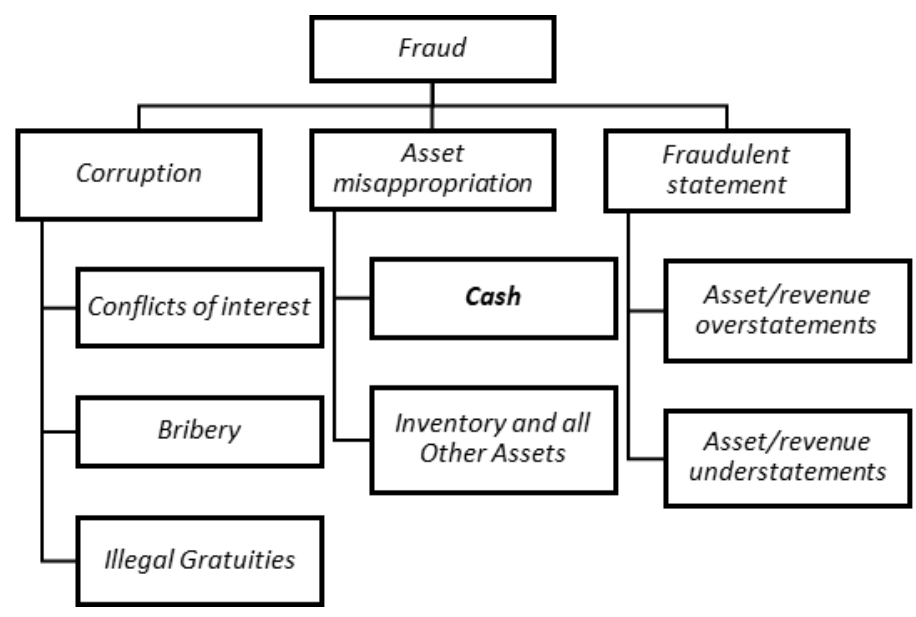

Figure 1 Fraud Tree

Source: Association of Certified Fraud Examiners (2019)

The fraud tree illustrates the main branches of fraud, such as corruption, asset misappropriation, and fraudulent statements.

\section{Hegemony Theory}

Hegemony literally means "leadership" and it is also used by political commentators to denote domination. Politically, hegemony means that self or group is better than others, therefore it becomes a desire to dominate because it feels worthy. According to Gramsci (1971) in Prison Notebooks "the ability of hegemony to undoubtedly presuppose the interests of groups leads to corporate-economic sacrifices." The public sector at the village government level shows that as a group of hegemonic institutions, the main objective of maintaining consensus and dominance in the society is to ensure a social group is obtained (Goddard, 2002).

Syarifuddin (2011) stated that hegemony can be shown in the power configuration, and budget policy changes, therefore, the policy-making process needs to be more oriented to the public. Furthermore, in terms of the issue of basic needs, the leader receives comprehensive support from the people (political power). On the other hand, this research also proves that the actors' ability to identify problems is also power or a power source.

\section{Hierarchy of Need Theory}

The famous psychologist Abraham Maslow proposed a theory of motivation based on universal human needs. Maslow believes that every individual has a hierarchy of needs, 
consisting of physiological, safety, social, self-esteem, and self-actualization needs, as shown in figure 2 .

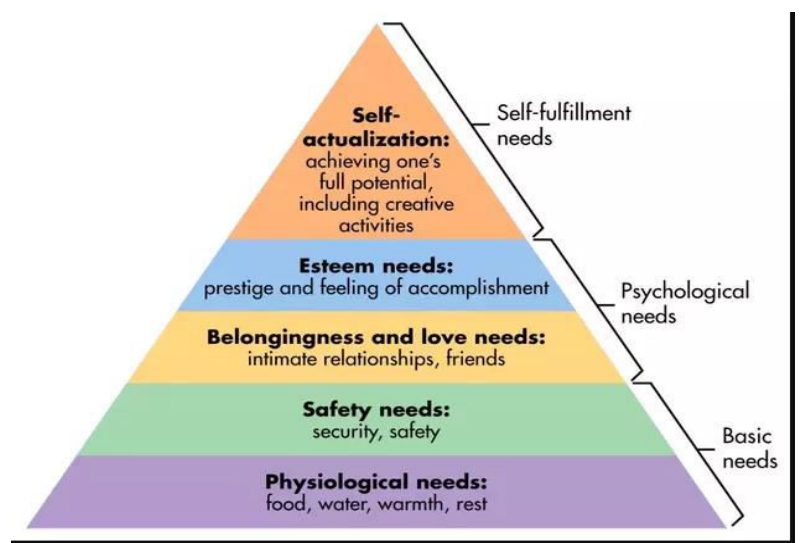

Figure 2 Maslow's hierarchy of needs

Source: Maslow, (1943) illustrated by Gitman, McDaniel, Shah, Reece, Koffel, Talsma, and Hyatt (2018) and Wang, (2018)

Maslow's theory of motivation indicates that people search for jobs to fulfill their basic needs, such as food, shelter, and clothing (Gitman et al., 2018). When they are able to provide these basic needs for themselves and families, they are in the physical and safety needs level of the hierarchy. According to Gitman et al., (2018) people need to feel safe, protected from physical harm, and avoid the unexpected, therefore, they need job security and protection from occupational hazards before trying to move up to the next step in order to reach the peak level, known as self-actualization.

\section{Law No. 6 of 2014}

Law Number 6 of 2014 mandates the government to allocate Village Funds to support the implementation of duties and functions for adequate development according to authority. The fund is budgeted annually in the State Budget, which is given to each village as a source of income. This policy simultaneously integrates and optimizes all existing budget allocation schemes from the government to villages, in accordance with Law No. 6 of 2014.

According to Hamzah (2015), funds sourced from the State Budget (APBN) and allocated to villages are transferred through the State General Treasury Account to the Regional Revenue and Expenditure Budget through the Regional General Treasury Account. The Village Fund is used to finance governance, public development, and community empowerment. The amount is gradually determined by $10 \%$ of the transfer funds to the regions. 


\section{Welfare/Remuneration based on Law no. 6 of 2014}

Based on the Regulation of the Minister for Administrative Reform and Bureaucratic State Apparatus Number 20 of 2010 regarding the Bureaucratic Reform Road Map, the 2010/2014 remuneration is defined as follows.

\footnotetext{
"Remuneration is all forms of compensation received by employees for their contribution to the organization. It is flexible, can be direct or indirect, cash or non-cash, with the provision of regular or basic salary, allowances, and other benefits."
}

APD welfare is regulated in Law no. 6 of 2014, where the central government provides fixed income, allowances, and incentives sourced from ADD (Village Fund Allocation) and managed by Regency. Since the enactment of the village law, APD salaries and allowances have been regulated in more detail by each region's regent, which refers to Government Regulations no 43 of 2014 concerning Guidelines. This is also associated with the implementation of Law No.6 of 2014 concerning villages, therefore the amount varies depending on the regent decision in each region. In 2019, the amount of APD Fixed Income was regulated with a minimum limit based on Government Regulation Number 11 of 2019 and in accordance with the Second Amendment to Government Regulation Number 43 of 2014 concerning Regulations of Law Implementation Number 6 of 2014.

\section{The Role of Village Officials in Law no. 6 of 2014 on the management of village funds}

The village's official roles and responsibilities have tremendously changed since the issuance of Village Law No. 6/2014. Prior to this law, many villages did not have physical buildings, such as offices, therefore activities were carried out at the village head's house. As changes occured, APD was required to be more committed to managing village affairs, especially in terms of time. According to the report, many village officials felt burdened at the beginning of the new law enactment in the Barito Kuala Regency and all regions in Indonesia (Kompak, 2016). The village head is mandated to carry out important roles in accordance with the Village Law no. 6 of 2014. Furthermore, the village secretary's administrative and accountability role increases due to changes in regulations.

Generally, village officials believe that they have little information with great demands that are not matched with their background and qualifications, which leads to numerous administrative errors (ID02, 2018). The role of the Village Head, which is important in terms of management, is limited by the energy spent in responding to requests from the communities. Therefore, they need to have the ability to carry out the managerial role, and this is also considered natural to the community.

In accordance with Law No.6 of 2014, the Village Consultative Agency (BPD) plays a role as an internal control in village government activities in managing funds. However, in this progress, the role and authority are unclear due to the various views of the BPD role, which led to conflicts. 


\section{Research Method}

\section{Types of research}

This is a qualitative research, with a case study approach used to identify local specific phenomena (Mahmudi, 2003), interplay of social settings where research was carried out (Hudaya, Smark, Watts, \& Silaen, 2015) and its implications to the policies made (Mahmudi, 2003). The research was conducted in Barito Kuala Regency, which is an underdeveloped subdistrict with an underdeveloped village index from 2015 to 2020, as shown in Table 1.

Three out of five villages in Subdistrict A were the object of in-depth observation in Barito Kuala Regency with coding used as the research object to maintain information confidentiality. This research was carried out from October 2017 to July 2019. Table 1 shows the information regarding the villages as the research objects.

Table 1 Table of the Village as a Research Object

\begin{tabular}{ccclll}
\hline No. & $\begin{array}{c}\text { Subdistrict } \\
\text { Code }\end{array}$ & $\begin{array}{c}\text { Village } \\
\text { Code }\end{array}$ & \multicolumn{1}{c}{ 2016 } & \multicolumn{1}{c}{ Village Status } & \multicolumn{1}{c}{$\mathbf{2 0 1 7}$} \\
\hline 1 & A & OD01 & Developing & Developing & Developed \\
2 & A & OD02 & Underdeveloped & Developing & Developing \\
3 & A & OD03 & Very underdeveloped & Underdeveloped & Underdeveloped \\
\hline
\end{tabular}

Source: Ministry of Village, 2019

This study started by carrying out field research through initial observations and interviews with officials in OD01 and OD02 villages. Furthermore, the snowball sampling technique was used to determine informants' competence, good knowledge, and credibility in answering any questions posed in the interview.

Table 2 Informants or Key Informants

\begin{tabular}{|c|c|c|c|c|c|}
\hline No. & Issue & Informant & Total & $\begin{array}{c}\text { Data Collection } \\
\text { Method } \\
\end{array}$ & Informant Code \\
\hline 1. & $\begin{array}{l}\text { Potential for Village } \\
\text { Fund Fraud }\end{array}$ & $\begin{array}{l}\text { On the central } \\
\text { and provincial } \\
\text { layers }\end{array}$ & $\begin{array}{l}\text { Seven } \\
\text { people }\end{array}$ & $\begin{array}{l}\text { Face to face interview, } \\
\text { through phone and } \\
\text { whatapps, transect }\end{array}$ & $\begin{array}{l}\text { IP (informant at } \\
\text { central/provincial } \\
\text { level) }\end{array}$ \\
\hline 2. & $\begin{array}{l}\text { a. Study of the } \\
\text { Village Funds and } \\
\text { Utilization in } \\
\text { South Kalimantan } \\
\text { b. Potential for } \\
\text { Village Fund Fraud }\end{array}$ & $\begin{array}{l}\text { On the } \\
\text { regency layer }\end{array}$ & $\begin{array}{c}12 \\
\text { people }\end{array}$ & $\begin{array}{l}\text { FGD, interview, } \\
\text { documentation, } \\
\text { transect }\end{array}$ & $\begin{array}{l}\text { IK (informant at } \\
\text { regency level) }\end{array}$ \\
\hline \multirow[t]{2}{*}{3.} & $\begin{array}{l}\text { Potential for Village } \\
\text { Fund Fraud }\end{array}$ & $\begin{array}{l}\text { On the village } \\
\text { layer }\end{array}$ & $\begin{array}{c}10 \\
\text { people }\end{array}$ & Interview and FGD & $\begin{array}{l}\text { ID (informant at village } \\
\text { level) with code W } \\
\text { given to distinguish } \\
\text { villagers from village } \\
\text { government } \\
\text { apparatus. }\end{array}$ \\
\hline & \multicolumn{2}{|c|}{ Total Informant } & $\begin{array}{c}25 \\
\text { people }\end{array}$ & & \\
\hline
\end{tabular}

Source: processed by the author, 2018 
The key informants were the Village Head, Secretary, and the Head of the Village Consultative Agency. Furthermore, data were obtained from village officials, community leaders, and related institutions such as Financial and Development Supervisory Agency (BPKP), Village Community Empowerment (PMD), Service Personnel, and Inspectorate. Table 2 shows the details of the informant data:

\section{Data collection technique}

Data were collected through transect, observation, interviews, and focus group discussions (FGD) with permission from the relevant agencies and informants. Interviews were carried out in a structured and unstructured manner through documentation, while FGDs were conducted at the beginning of the research to explore issues related to village funds.

The use of interview and FGD techniques in the data collection method depended on the informants' time availability, followed by documentation and transect in a way that is considered appropriate and relevant in assessing rural environmental conditions. Sources of evidence in the form of documents are also obtained from agencies, informants, and related parties, in the form of recorded interviews, archives, resumes, and direct observation.

\section{Data analysis technique}

According to Yin, (2018) data analysis is the process of categorizing, tabulating, and combining evidence to refer to the initial proposition of a study. Furthermore, it is a filter for disconfirming evidence or deviance. Creswell and Creswell, (2018) highlighted that triangulation process in qualitative research is needed to enhance reliability and internal validity of the data as shown in the Figure 3 .

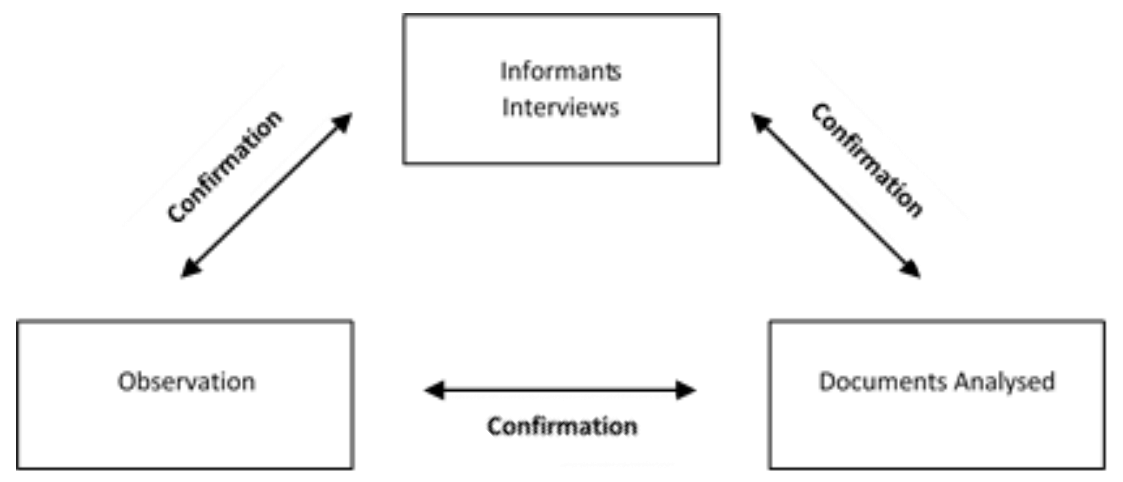

Figure 3 Illustration of the triangulation process

Source: referring to Creswell and Creswell, (2018)

According to Yin, (2018), there are five analysis techniques for the case study approach, namely pattern matching, building explanations, time series analysis, logic models, and cross-case synthesis. This research uses pattern matching techniques to analyze the 
problem under study and answer questions regarding the research objectives. Sinkovics, (2018) stated that pattern matching involves comparing the predicted theoretical pattern with the observed empirical pattern. The underlying assumption is that humans understand the world by comparing their external observation with the model patterns, which also exists to some degree in cases where the pattern match is not explicit. Similarly, applying pattern-matching logic causes a more rigorous as well as structured research and writing process. Gerring, (2017); Marshall and Rossman, (2016) highlighted the importance data reduction over data gathered before pattern matching analysis was conducted. Data reduction process helped researchers in sorting out the relevant data processed in pattern matching analysis. We then theorized the research process and pattern matching analysis as shown in the figure 4.

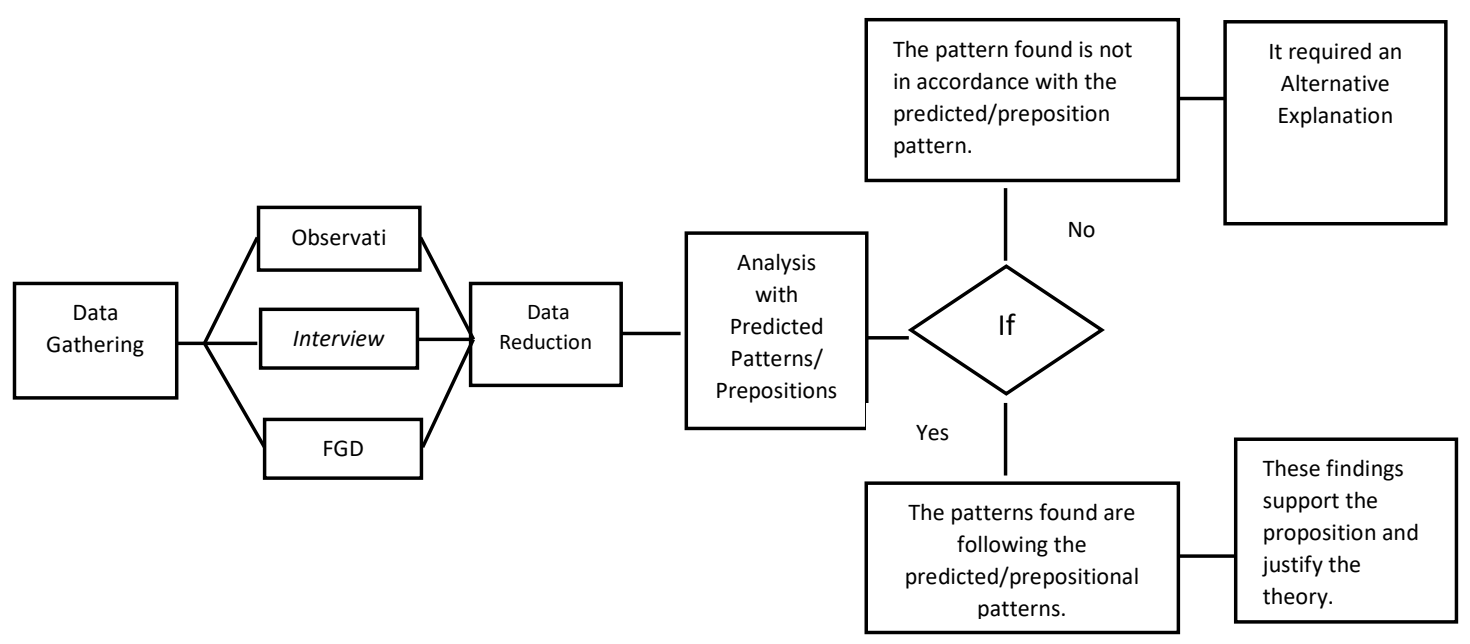

Figure 4 Research Process and Pattern Matching

Source: developed from Gerring, (2017); Marshall and Rossman, (2016); Sinkovics, (2018); Yin, (2018)

The pattern matching process is divided into three steps or practical phases, namely stating a research proposition (when needed), examining the empirically found patterns of each different method against the predicted ones, and providing theoretical explanations with research results (Yin, 2015).

\section{Result and Discussion}

Before presenting the results, it is necessary to reemphasize that this study aims to determine the factors that cause fraud and the relationship with the remuneration received by the village government Apparatus (APD). The results stated that the research was divided into exposure to fraud cases in Barito Kuala Regency, with the APD welfare mapped to determine the return and risk received. 


\section{Fraud Case in Barito Kuala Regency}

From 2015 to early 2020, there were 4 cases of fraud/corruption in village funds at Barito Kuala Regency, as shown in tables 3 and 4.

Table 3 Ongoing fraud (corruption) cases

\begin{tabular}{cllll}
\hline No. & \multicolumn{1}{c}{ Village } & Defendant & \multicolumn{1}{c}{ Subdistrict } & Case Development \\
\hline 1. & $\begin{array}{l}\text { Pulau Sugara } \\
\text { Village. }\end{array}$ & Village head & Alalak & $\begin{array}{l}\text { Banjarmasin District } \\
\text { Court Session }\end{array}$ \\
2. $\begin{array}{l}\text { Sungai Seluang } \\
\text { Village }\end{array}$ & Village head & Belawang & $\begin{array}{l}\text { Banjarmasin District } \\
\text { Court Session }\end{array}$ \\
\hline
\end{tabular}

Souce: (Banjarmasinpost, 2020b, 2020a)

Table 4 Fraud (Corruption) cases that have received a verdict

\begin{tabular}{cllll}
\hline No. & \multicolumn{1}{c}{ Village } & \multicolumn{1}{c}{ Convict } & \multicolumn{1}{c|}{ Decision } & \\
\hline 1. & $\begin{array}{l}\text { Pindahan Baru } \\
\text { Village, Rantau } \\
\text { Badauh Subdistrict }\end{array}$ & $\begin{array}{l}\text { H Bunyamin, } \\
\text { Village head }\end{array}$ & With a legal force & $\begin{array}{l}\text { No. 8/pid.sus- } \\
\text { tpk/2017/pn.bjm }\end{array}$ \\
2. $\begin{array}{l}\text { Sungai Rasau, } \\
\text { Cerbon Subdistrict }\end{array}$ & $\begin{array}{l}\text { Bahrun, Village } \\
\text { head }\end{array}$ & With a legal force & $\begin{array}{l}\text { No 12/Pid.Sus- } \\
\text { TPK/2019/PN. } \\
\text { Bjm. }\end{array}$ \\
\hline
\end{tabular}

Souce: Indonesian Directory of Supreme Court Decisions, 2019

The tables show that there are a total of 4 cases with 2 having received final legal decisions (inkracht van gewijsde), while the remaining 2 are undergoing trial.

\section{Mapping of APD Welfare in Barito Kuala Subdistrict}

Members of APD and their families have been worried about their welfare since the Village Law enactment. This encouraged them to carry out demands and commitments for long working hours. Initially, working as village officials were voluntary because most APD had businesses or other jobs to support them.

APD welfare in Indonesia is currently based on the amount of money received, which widely varies (Kompak, 2016). Based on the Reality Checking Approach on Local Perspectives and Experiences towards the Village Law Indonesia in early 2016, 70\% of ADD was used to pay for APD welfare, with a village secretary paid with civil salary scale servants appointed directly by the regent. The APD welfare in Indonesia and especially for Barito Kuala Subdistrict, is measured by the provision of salaries, allowances, and incentives as shown in table 5 . 
Yuliastina, Hudaya, Nor, \& Ainun

New Remuneration System for Village Government Apparatus (APD): ...

Table 5 APD remuneration in 2016

\begin{tabular}{|c|c|c|c|c|c|c|c|c|c|c|}
\hline \multirow[t]{2}{*}{ No } & \multirow{2}{*}{$\begin{array}{l}\text { Description } \\
\text { (Position) }\end{array}$} & \multicolumn{3}{|c|}{2016} & \multicolumn{3}{|c|}{2017} & \multicolumn{3}{|c|}{2018} \\
\hline & & $\begin{array}{l}\text { Total } \\
\text { remuneration } \\
\text { received }\end{array}$ & & $\begin{array}{c}\text { Regional } \\
\text { Minimum } \\
\text { Wage of } \\
\text { Barito Kuala } \\
\text { Regency }\end{array}$ & $\begin{array}{l}\text { Total } \\
\text { remuneration } \\
\text { received }\end{array}$ & & $\begin{array}{c}\text { Regional } \\
\text { Minimum } \\
\text { Wage of } \\
\text { Barito Kuala } \\
\text { Regency }\end{array}$ & $\begin{array}{l}\text { Total } \\
\text { remuneration } \\
\text { received }\end{array}$ & & $\begin{array}{c}\text { Regional } \\
\text { Minimum } \\
\text { Wage of } \\
\text { Barito Kuala } \\
\text { Regency }\end{array}$ \\
\hline \multicolumn{11}{|c|}{ VILLAGE GOVERNMENT APPARATUS (APD) } \\
\hline 1. & Village head & Rp. 2,500,000,- & $*$ & Rp. $2,085,050,-$ & Rp. $2,800,000,-$ & $*$ & Rp. 2,258,000,- & Rp. 5,100,000,- & $*$ & Rp. $2,651,781,-$ \\
\hline 2. & Village Secretary & Rp $1,770,000,-$ & $* *$ & & Rp. $2,010,000,-$ & $* *$ & & Rp. $3,620,000,-$ & $*$ & \\
\hline 3. & Head of Affairs & Rp. $1,300,000,-$ & $* *$ & & Rp. $1,500,000,-$ & $* *$ & & Rp. $2,650,000,-$ & $* *$ & \\
\hline 4. & Head of Division & Rp. 1,300,000,- & $* *$ & & Rp. $1,500,000,-$ & $* *$ & & Rp. $2,650,000,-$ & $* *$ & \\
\hline 5. & $\begin{array}{l}\text { Village } \\
\text { Treasurer }\end{array}$ & Rp. $900,000,-$ & $* *$ & & Rp. $1,250,000,-$ & $* *$ & & Rp. 2,350,000,- & $* *$ & \\
\hline 6. & Asset Treasurer & & & & Rp. $1,000,000,-$ & $* *$ & & Rp. $2,100,000,-$ & $* *$ & \\
\hline \multicolumn{11}{|c|}{ VILLAGE CONSULTATIVE AGENCY (BPD) } \\
\hline 1. & Chairman & Rp. $\quad 400,000,-$ & $* *$ & Rp. 2,085,050,- & Rp. $500,000,-$ & $* *$ & Rp. $2,258,000,-$ & Rp. $\quad 500,000,-$ & $* *$ & Rp. $2,651,781,-$ \\
\hline 2. & Vice Chairman & Rp. $350,000,-$ & $* *$ & & Rp. $\quad 450,000,-$ & $* *$ & & Rp. $\quad 500,000,-$ & $* *$ & \\
\hline 3. & Secretary & Rp. $350,000,-$ & $* *$ & & Rp. $\quad 450,000,-$ & $* *$ & & Rp. $\quad 500,000,-$ & $* *$ & \\
\hline 4. & Member & Rp. $300,000,-$ & $* *$ & & Rp. $\quad 400,000,-$ & $* *$ & & Rp. $\quad 450,000,-$ & $* *$ & \\
\hline \multicolumn{11}{|c|}{ Neighborhood (RT) and Hamlet (RW) } \\
\hline 1. & Neighborhood & Rp. $\quad 150,000,-$ & $* *$ & Rp. $2,085,050,-$ & Rp. $150,000,-$ & $* *$ & Rp. $2,258,000,-$ & Rp. $\quad 150,000,-$ & $* *$ & Rp. $2,651,781,-$ \\
\hline 2. & Hamlet & Rp. $\quad 150,000,-$ & $* *$ & & Rp. $150,000,-$ & $* *$ & & Rp. $150,000,-$ & $* *$ & \\
\hline
\end{tabular}

Notes: for categories above the Regional Minimum Wage (UMR), is given with an * sign and for below the UMR is given with an ** sign Source: Barito Kuala Regency Regent Regulation Number 54 of 2015 
Law No.6 2014 was the starting point of the implementation and disbursement of village funds in 2016. The APD welfare is still below the UMR for Barito Kuala Regency, except for the village head. In 2016, Barito Kuala had 195 villages with 16, 147, 32, and 0 villages underdeveloped, underdeveloped, developing, and developed. The welfare conditions (remuneration) for PPE in 2017 were also the same in all the villages. However, based on IDM, 13, 125, 53, and 4 villages were very underdeveloped, underdeveloped, developing, and developed in 2017. This means that there is status progress in 46 villages, while 127 are still with the same status and 20 decreased when compared to IDM data in 2016.

APD remuneration in 2018 significantly increased, as shown from the salaries of village heads and secretaries that far exceeded the UMR for Barito Kuala Regency. Heads of affairs and divisions are still in the lower limit, however the value is not significant with the remuneration received by the village and asset treasurer below the UMR. This needs to be a concern because the village and asset treasurer are in direct contact with financial management and similar to BPD's amount, which is $1 / 5$ of the UMR. In the end, it can be concluded that the total amount received by APD, especially in the top village management, gradually increases yearly.

This increase in value is because the obtained nominals obtained have far exceeded the UMR, especially for the Village Head. However, based on the APD statement, village heads spend many funds to fulfill their constituencies (ID02, 2018). The village head also plays the role of protecting the community, and it is not uncommon for them to attend weddings, funerals, and other events, therefore they need funds for these activities which are not obtained from the village budget.

In 2019, the village head's regular income was Rp. 2,426,640, or equivalent to $120 \%$ of class II/a civil servant's salary. Meanwhile, the village secretary's regular income was at least Rp. $2,224,420$, or equivalent to $110 \%$ of class II /a civil servant's salary. Furthermore, the other village officials' regular income is at least Rp. 2,022,200, or equivalent to $100 \%$ of class II/a civil servant's salary. These are based on the government Regulation Number 11 of 2019, the second amendment Regulation Number 43 of 2014, and Regulations for Law Implementation Number 6 of 2014 on Villages. In addition, the district/city minimum wage (UMK) set for Barito Kuala Regency in 2019 is Rp. 2.6 million rupiahs.

The APD remuneration distribution depends on the village funds allocation (ADD) from the Regional Revenue and Expenditure Budget with the regentregent's policies. Although the amount earned has gradually increased, there are indeed several position levels that receive salaries, allowances, and incentives under the legislation provisions (Labor Law). Furthermore, APD welfare/remuneration increases when juxtaposed with the village welfare represented by the Developing Village Index (IDM). Table 6 describes the village status development in Barito Kuala Regency from 2017 to 2019. 
Yuliastina, Hudaya, Nor, \& Ainun

New Remuneration System for Village Government Apparatus (APD): ...

Table 6 Description of Village Status Development in Barito Kuala Regency 2016-2019

\begin{tabular}{cccccccccc|}
\hline Independent & Developed & \multicolumn{1}{c}{ Developing } & Underdeveloped & \multicolumn{2}{c}{$\begin{array}{c}\text { Very } \\
\text { Underdeveloped }\end{array}$} \\
\hline 2016 & 2020 & 2016 & 2020 & 2016 & 2020 & 2016 & 2020 & 2016 & 2020 \\
0 & 1 & 0 & 8 & 32 & 133 & 147 & 51 & 16 & 2 \\
\hline
\end{tabular}

Source: Developing Village Index, 2020

Overall, since the village fund's existence, the number of underdeveloped areas in Barito Kuala Regency has drastically decreased for 4 years. When related to the APD role and welfare, it is also very impactful with the Village Law's existence and the regulation of roles with a gradual change in welfare.

\section{GAP of Village Government Apparatus Welfare/Remuneration}

Welfare/remuneration between position levels in different organizations creates gaps

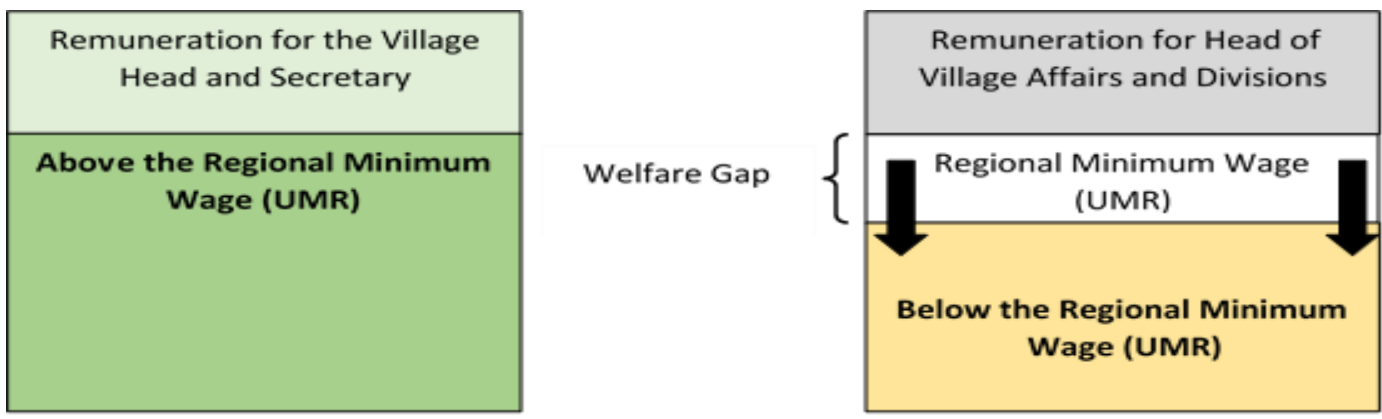

Figure 5 The new APD remuneration system creates a welfare gap (remuneration received)

Figure 5 shows that the remuneration at the top management level is above the Indonesian Law standards Number 13 of 2003 concerning Manpower. Furthermore, the welfare gap can turn into a potential fraud gap in APD's motivation to fulfill basic needs.

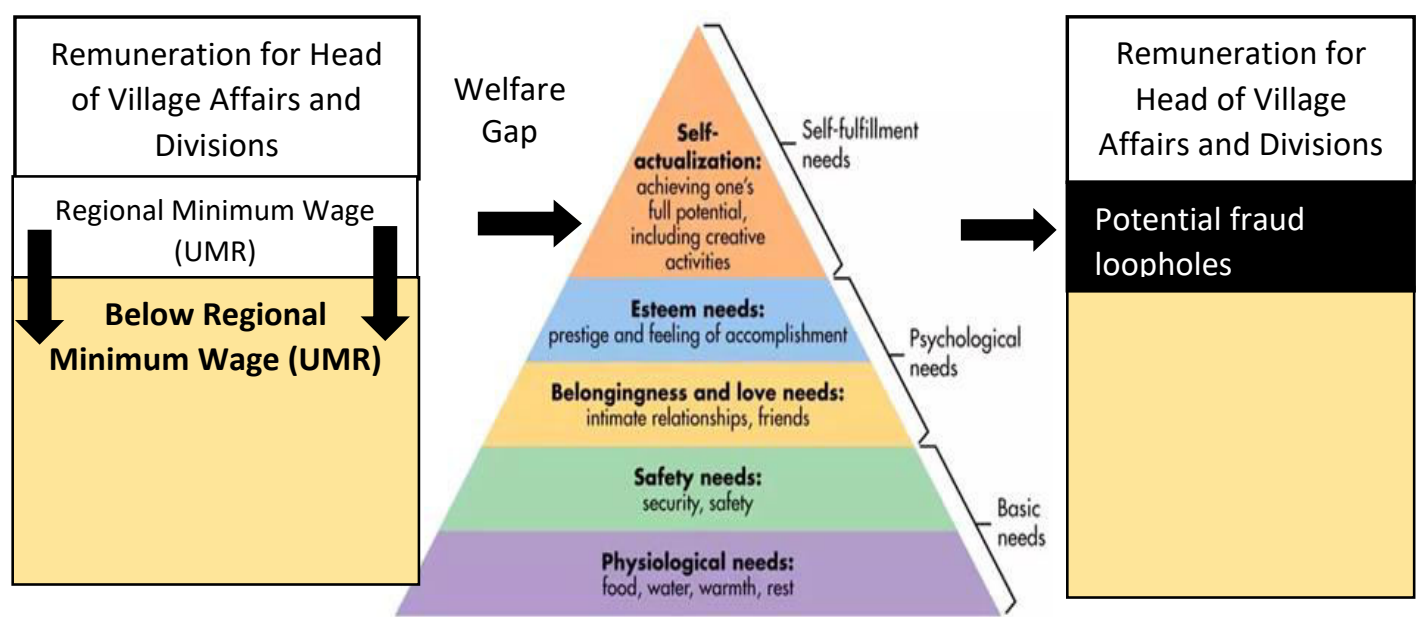

Figure 6 Pattern Matching: The welfare gap promotes the emergence of a potential fraud gap 
The pattern in figure 6 shows that there are loopholes (gaps) in the village government apparatus (APD) remuneration system, therefore, they need to ensure that all APD receive a monthly income, similar to the UMR standard. Furthermore, when the APD is still struggling to live properly at a minimum, it is inappropriate for the government to demand that they fight to bring prosperity to their village residents. On the other hand, APD is also involved in managing village funds, which leads them into the temptation of utilizing it for their personal needs.

\section{Village Government Apparatus Profession: High Risk, Low Return?}

People work for various reasons, such as earning some money, facing challenges, and gaining security. Therefore, organizations need to decide what people need in a workplace and ensure they play an essential role in motivating them. APD, as a worker, needs to have a certain motivation at work in order to fulfil their levels and hierarchy of needs (Maslow, 1943). Therefore, the following is an excerpt from participants in the Focus Group Discussion (FGD) on the Study of the Village Funds Utilization in South Kalimantan (2018) "Village heads do have great potential to carried out misuse due to their power." According to the hegemony theory by Gramsci (1971), the power possessed by the village head plays a vital role in development, in accordance with Law No. 6 of 2014, which requires the principle of self-management. Villages are built together by the community and for the community.

The potential for criminalization is also high due to the ignorance of correct administrative handling and the large funds that need to be managed by the village government. Based on a statement from the Provincial Assistant Coordinating Officer, one of the Village Heads in Barito Kuala Regency had problems with 300 million-rupiah funds and is currently held as a fugitive (IP06, 2018). The same information was also disclosed by a village official in Barito Kuala Regency in the following excerpt.

\footnotetext{
"In Regency Barito Kuala, a Village Head was tried in court and is still in the appeal process from OD05. There are indications of administrative falsification starting from meetings, with nepotism indications for implementing family-related work, fictitious projects, and mark-ups." (ID02, 2018)
}

In Village OD05, there was a fraud case where the Village Head and family were the dominant actors involved in using the Village Fund. Generally, and based on many studies and literature, fraud occurs a lot due to pressure in terms of financial, opportunity, rationalization, ego, stimulus, capability and collution. However, in hegemony, the village head's full power is one of the potential causes of fraud.

Village funds provided by the central government are the main reasons behind the participation of several parties in elections. The village head is seen as a symbol of the highest social sovereignty and the landlady communities directly or indirectly with them. According to a statement released by an official in a village of Barito Kuala Regency (2018), 
"Since the distribution of funds in 2015, which is approximately 1 billion rupiahs, many people have become interested in becoming village heads." (IK05, 2018)

Full power is associated with the fraud theory, which fulfils opportunity, ego, stimulus, and capability.

The competition for Village Heads creates high political costs, with some parties still have the wrong perception of village funds because the majority considers its operational costs. Furthermore, the high political costs cause problems in the future. Officials that win elections using money always use the opportunity to return the initial capital used for winning (ID02, 2018), thereby creating collusion during the process. This is in line with (Kompak, 2016) regarding the Reality Checking Approach on Local Perspectives and Experiences towards the Village Law in Indonesia 2016.

One of the villages, used as an object for in-depth research experienced high political costs during elections, different from the winning party that served for two periods (ID02, 2018). Due to the defeat, the losing party attacked the incumbent government with news in the form of fraud cases. The news obtained into the local media, and after proper analysis, it turned out that it was carried out by the political opponents that lost the election. The practice of cultural hegemony also occurs in this area where a group of people wants to maintain power in various ways and this is resolved by clarification (ID02, 2018).

Financial pressure, such as high political costs due to the village head election, is the main reason for fraud. The power of the Village Head as the Financial Management Power Holder (PKPKD) creates potential opportunities for fraud. According to the Minister of Home Affairs Regulation No. 20/2018 the authority delegation to village secretaries and officials act as Regional Financial Management Officers (PPKD) for the prevention of fraud associated with Village Funds. Therefore, the village officials in Barito Kuala District stated the following:

"In the previous regulation, PPKD was absolutely the village head responsibility, and with the issuance of new regulations enacted in 2019 , the role was delegated to the Village Secretary, therefore the Village Head and the Secretary worked together."(ID02, 2018)

This regulation became effective in 2019, thereby leading to changes in the Minister of Home Affairs Regulation No. 20/2018 regarding village financial management which was previously regulated in the Minister of Home Affairs Regulation No. 113/2014. The village secretary currently acts as both the PPKD coordinator and the PTPKD in accordance with regulation No. 20/2018, with the treasury function carried out by the Head of Finance. The activity initially carried out by the Village Treasurer in the Barito Kuala Regency was appointed outside the structure of the Village Apparatus and divided into Asset and Goods Treasurers. The village officials and their family were also potential fraud perpetrators, which arises from the formation of an Activity Management Team by the Village Head. Based on Regional Head Regulations concerning Government Goods/Services Procurement Policy Institutions (LKPP) Number 22 of 2015 which was changed to 13/2013 concerning Guidelines for Procurement Procedures of Government 
Goods and Services in the village, the Activity Management Team (TPK) is a team established by the village head in accordance with the services carried out by the government and community.

Opportunity to commit fraud is created in the form of less strict regulations regarding those to be appointed as TPK members. According to a village official in Barito Kuala Regency $(I D 02,2018)$ regulations need to be made clear, and chosen from the village community, to prevent the misinterpretation and to prevent unwanted attributes. This reinforces the regulations ambiguity governing the formation of the TPK team and causes misinterpretation.

The potential fraud perpetrators are not only the Village Head rather they are also officials and their families. This is strengthened by the Indonesia Corruption Watch, (2018) research, which stated that all fraud cases involve the Village Head as the main actor, APD, and family. The Village Heads involved 112 (one hundred and twelve) people, which continues to increase significantly every year. A total of 15 (fifteen), 32, and 65 village heads were elected in 2015, 2016, and 2017. However, not all actors are Village Heads, therefore, there were 32 officials and three village head family (Indonesia Corruption Watch, 2017).

This potential needs the preventive action and supervision of the community, therefore from the discussion of the Village Mid-Term Development Plan as well as the Village Income and Expenditure Budget, it is important to promote monitoring participation. Furthermore, there is a need for counter-hegemony in the power domination owned by the Village Government. According to Maslow, (1943), the assumption to achieve welfare by instilling power also needs to be straightened out because morals are more important in achieving common prosperity.

\section{Village Fund: Bring Welfare or Danger}

Village officials stated that the compensation received was still minimal and not in accordance with the risks received. Furthermore, at some levels, their salary is below the standard minimum wage. Therefore, based on the fact that APD is also a worker, everything refers to Indonesian Law Number 13 of 2003 concerning Manpower (2003). In Article 89, the minimum wage is defined as (1) the minimum wage based on the province or regency/city area and (2) minimum wage based on sector in the province or regency/ city. The following is an excerpt from one of the village officials.

"At least, each level received compensation in accordance with the law, therefore, it does not a cause for the need to commit fraud"(ID02, 2018).

A similar statement was also conveyed by the participants of the FGD regarding the Study of the Village Funds Utilization in South Kalimantan (2018)

"Compensation for village officials is very minimal, therefore, they also need to benefit from the funds. The biggest benefit of village funds for officials is dealing with law enforcement officials (APH), which causes energy drain." (IK05, 2018) 
Based on the motivation theory, namely the hierarchy of needs proposed by Maslow, (1943), workers basic needs, such as clothing, food, and shelter, need to be fulfilled in order to motivate them (Gitman et al., 2018). A person that works to fulfil the needs of others, is a public servant, and when their basic needs are not fulfilled, there is a potential for the occurrence of fraud.

The preliminary interview carried out at the beginning of this study was in accordance with Kompak's (2016) research, which stated that the Village Government Apparatus is a part-time job, therefore, the parties involved need to be traders, company workers, farmers, etc (ID02, 2018). This is in accordance with law No.6 of 2014, which needs APD to work professionally and full time. The potential for fraud on village funds originates from the budget, as illustrated in the case that occurred in several villages in Barito Kuala Regency. Cases number 1 and 2 are associated with fraud committed by village heads' to enrich themselves, which is against the law. This is based on the inkracht decision No.8/pid.sus-tpk/2017/pn.bjm and Number 12/Pid.Sus-TPK/2019/PN. Furthermore, unsupervised budget planning leads to non-optimal implementation of the budget (SiLPA). These impacts cause potential fraud with the Village Fund, therefore, transparent, participatory and accountable budget management is the solution to the main problems of corruption cases in villages. Finally, special attention is needed for village fund management to be adequately managed with reliable reports.

\section{Conclusion}

In conclusion, it is important to increase the remuneration received by the Village Apparatus (APD) as a driving factor in running village governance for proper funds management. The remuneration received, especially at the middle and low-level management, is still below the Regional/Provincial Minimum Wage (UMR/P). This tends to create new problems, that causes a pay gap in salary or remuneration among village officials. Furthermore, the APD minimum welfare is not in line with their responsibilities where they need to be professional in carrying out their duties.

The main APD task is in village development, however, the compensation for the workload received is not proportional to the risks faced, therefore they experience a high risk with low return condition. In addition, the central and local governments tried to overcome the village fund fraud problem by increasing APD salaries and welfare. However, the increase was limited to the village head and secretary, while the head of affairs and division were still under the minimum wage (UMR). Therefore, based on these conditions, the strength of the new remuneration system in suppressing the fraud potential is still in doubt, with new loopholes or gap. In other words, this uneven APD remuneration increase becomes difficult to mitigate, and eliminate the potential in funds managed by APD.

Other factors that cause fraud are the over power possessed by village top management, therefore, transparency is needed for participatory and accountable budget management. Furthermore, promoting community participatory efforts as a 
form of counter-hegemony make the self-management principle to be achieved. This can also be a form of fraud mitigation, besides building the idea that power in top management is not meant to achieve mutual prosperity.

The central and local governments need to respond to the differences in remuneration between the upper, middle, and lower levels of the village government apparatus (APD) because this creates a new gap that can lead to new problems, including potential fraud. Every APD is required to work full time, however the remuneration received is not full at the regional minimum wage (UMR) standard. Therefore, the government also need to mitigate fraud by building participatory public awareness and improving their remuneration.

This research was carried out using a qualitative approach, thereby making it difficult for the results to be generalized to a broader scope. Research themes on fraud are sensitive in collecting data, this is because access is needed from credible external sources. Although not all fraud data was collected, an understanding of the data triangulation process helped to solve the problems.

Further research needs to be carried out to determine the extent of the central and regional governments' response in overcoming the gaps in the asymmetric APD remuneration system. This is because others are still struggling to make themselves prosperous and welfare.

\section{References}

Abbink, K. (2002). Fair salaries and the moral costs of corruption. Bonn Econ Discussion Papers 1/2000, University of Bonn, Bonn Graduate School of Economics (BGSE). Retrieved from http://www.nottingham.ac.uk/cedex/documents/papers/200205.pdf

Albrecht, W. S., Albrecht, C. O., Albrecht, C. C., \& Zimbelman, M. F. (2015). Fraud examination. In South-Western Cengage Learning (Fifth Edit). Boston: Cengage Learning.

Association of Certified Fraud Examiners. (2016). Report to the nations on occupational fraud and abuse. Retrieved from https://www.acfe.com/rttn2016/docs/2016-report-to-thenations.pdf

Association of Certified Fraud Examiners. (2019). Fraud tree. Retrieved from https://www.acfe.com/fraud-tree.aspx

Banjarmasinpost. (2020a). Video kades sungai saluang duduk jadi terdakwa kasus korupsi, diduga selenvengkan dana desa. Retrieved from Banjarmasin Post. Available at https://banjarmasin.tribunnews.com/2020/02/18/video-kades-sungai-saluangduduk-jadi-terdakwa-kasus-korupsi-diduga-selewengkan-dana-desa

Banjarmasinpost. (2020b). Video sidang korupsi dana desa, kades pulau sugara dengarkan keterangan saksi. Retrieved from Banjarmasin Post. Available at https://banjarmasin.tribunnews.com/2020/04/27/video-sidang-korupsi-dana-desakades-pulau-sugara-dengarkan-keterangan-saksi

Becker, G. S., \& Stigler, G. J. (1974). Law enforcement, malfeasance, and compensation of enforcers. The Journal of Legal Studies, 3(1), 1-18. https://doi.org/10.1086/467507 
Blackburn, K., Bose, N., \& Haque, M. E. (2011). Public expenditures, bureaucratic corruption and economic development. Manchester School, 79(3), 405-428. https://doi.org/10.1111/i.1467-9957.2009.02168.x

Creswell, J. W., \& Creswell, J. D. (2018). Research design: Qualitative, Quantitative and Mixed Methods Approaches (Fifth Edit). SAGE Publications, Inc.

DitjendPDT. (2017). Penerima dana desa di 2017 naik jadi 74.954 desa. Retrieved from Direktorat Jendral Pembangunan Daerah Tertinggal. Available at http://ditjenpdt.kemendesa.go.id/news/read/170110/393-penerima-dana-desa-di2017-naik-jadi-74-954-desa

Gerring, J. (2017). Case study research principles and practices (Second Edition). Cambridge University Press.

Gitman, L. J., McDaniel, C., Shah, A., Reece, M., Koffel, L., Talsma, B., \& Hyatt, J. C. (2018). Introduction to business. OpenStax.

Goddard, A. (2002). Development of the accounting profession and practices in the public sector a hegemonic analysis. Accounting, Auditing \& Accountability Journal 15(5), 655688. https://doi.org/10.1108/09513570210448957

Gong, T., \& Wu, A. M. (2012). Does increased civil service pay deter corruption? evidence from China. Review of Public Personnel Administration, 32(2), 192-204. https://doi.org/10.1177/0734371X12438247

Gramsci, A. (1971). Selections from the prison notebooks. International Publishers Co.

Hamzah, A. (2015). Tata kelola pemerintahan desa: menuju desa mandiri, sejabtera dan partisipatoris. Surabaya: Penerbit Pustaka.

Hudaya, M., Smark, C., Watts, T., \& Silaen, P. (2015). The use of accountability reports and the accountability forum: Evidence from an indonesian local government. Australasian Accounting, Business and Finance Journal, 9(4), 57-70. https://doi.org/10.14453/aabfi.v9i4.5

ID02. (2018). Wawancara: Pembinaan dan pengawasan dana desa di desa OD01.

IK05. (2018). FGD: Studi pemanfaatan dana desa.

Indonesia Corruption Watch. (2017). Cegah korupsi dana desa. Retrieved from Indonesia Corruption Watch. Available at https://antikorupsi.org/id/news/cegah-korupsidana-desa

Indonesia Corruption Watch. (2018). Outlook dana desa 2018 potensi penyalahgunaan anggaran desa di tahun politik (issue 6). Retrieved from Indonesia Corruption Watch. Available at https://antikorupsi.org/sites/default/files/outlook desa_2018__icw.pdf

IP03; IP04. (2017). Wawancara: Pembinaan dan pengawasan dana desa di Kalimantan Selatan.

Klikkalsel. (2019). "Makan" dana desa ratusan juta, pembakal sungai rasau ditangkap Polres Batola. Retrieved from Klikkalses. Available at https://klikkalsel.com/makan-dana-desaratusan-juta-pembakal-sungai-rasau-ditangkap-polres-batola/

Komisi Pemberantasan Korupsi. (2015). Laporan hasil kajian pengelolaan keuangan desa; Alokasi dana desa dan dana desa. Retrieved from Deputi Bidang Pencegahan KPK. Available at https://acch.kpk.go.id/id/component/bdthemes shortcodes/?view=download\&id $=$ bd20cd6416656c2a441659f4bb77ab

Kompak. (2016). Laporan reality check approach: Perspektif dan pengalaman lokal terbadap un desa di Indonesia. Retrieved from Kolaborasi Masyarakat dan Pelayanan untuk Kesejahteraan (kompak). Available at https://kompak.or.id/storage/app/media/Publication/3 laporan_penelitian_dan_e valuasi/Laporan-Reality-Check-Approach-Perspektif-dan-Pengalaman-Lokalterhadap-UU-Desa-di-Indonesia-doc-distribution.pdf 
Kompas. (2018). Kepala desa diminta segera lapor jikea ada upaya kriminalisasi. Retrieved from Kompas. Available at https://nasional.kompas.com/read/2017/08/19/15013921/kepala-desa-dimintasegera-lapor-jika-ada-upaya-kriminalisasi

Kornai, J., Haggard, S., \& Kaufman, R. R. (2001). Reforming state fiscal and welfare reform post socialist countries. Cambridge University Press.

Kumparan. (2018). Kades di Barito Kuala kabur setelah menyelewengkean dana desa. Retrieved from Kumparan. Available at https://kumparan.com/banjarhits/sembrono-pakai-danadesa-kades-di-barito-kuala-menghilang

Lederman, D., Loayza, N., \& Soares, R. R. (2007). Accountability and corruption: Political institutions matter. Policy Research Working Papers. https://doi.org/10.1596/1813$\underline{\text { 9450-2708 }}$

Liu, J., \& Lin, B. (2012). Government auditing and corruption control: Evidence from China's provincial panel data. China Journal of Accounting Research, 5(2), 163-186. https://doi.org/10.1016/j.cjar.2012.01.002

Mahmudi. (2003). Studi kasus sebagai strategi riset untuk mengembangkan akuntansi sektor publik. Jurnal Akuntansi \& Auditing Indonesia, 7(1), 51-65. Retrieved from https://journal.uii.ac.id/JAAI/article/view/850

Marshall, C., \& Rossman, G. B. (2016). Designing qualitative research (sixth edit). Sage Publication Inc.

Maslow, A. H. (1943). A theory of human motivation. Psychological Review, 50(4), 370-396. https://doi.org/10.1037/h0054346

Okezone News. (2017). Gara-gara dana desa, banyak wilayah ingin pemekaran. Retrieved from Okezone. Available at https://news.okezone.com/read/2017/02/10/340/1614536/gara-gara-dana-desabanyak-wilayah-ingin-pemekaran

Oktavia, T. A., Sayekti, Y., \& Prasetyo, W. (2018). The effect of compensation to detection fraud in village government (empirical study on sub-district of Pasirian, district of Lumajang). International Journal of New Technology and Research, 4(6), 68-70. Retrieved from https://www.ijntr.org/download data/IJNTR04060011.pdf

Pellegrini, L. (2011). Corruption, development and the environm ent. Springer Netherlands.

Rauch, J. E., \& Evans, P. B. (2000). Bureaucratic structure and bureaucratic performance in. Journal of Public Economics, 75(1), 49-71. https://doi.org/10.1016/s00472727(99)00044-4

Republika.co.id. (2017). Mendes minta penegak hukum tak kriminalisasi kepala desa. Retrieved from Republika Online. Available at https://www.republika.co.id/berita/nasional/umum/18/11/25/piqw2m335mendes-minta-penegak-hukum-tak-kriminalisasi-kepala-desa

Sinkovics, N. (2018). The importance of pattern matching for business and management studies. The SAGE Handbook of Qualitative Business and Management Research Methods: Methods and Challenges.

Sofyani, H., Suryanto, R., Wibowo, S. A., \& Widiastuti, H. (2018). Praktik pengelolaan dan tata kelola pemerintahan desa Dlingo di kabupaten Bantul: Pembelajaran dari desa percontohan. Jati: Jurnal Akuntansi Terapan Indonesia, 1(1), 1-16. https://doi.org/10.18196/jati.010101

Syahroni, Maharso, \& Sujarwadi, T. (2018). Korupsi, bukan budaya tetapi penyakit. Yogyakarta: Deepublish Publisher.

Syarifuddin. (2011). Konstruksi kebijakan anggaran: Aksentuasi drama politik dan kekuasaan (studi kasus kabupaten Jembrana Bali). EKUIT AS (Jumal Ekonomi dan Kenangan), 15(3), 307-331. http://dx.doi.org/10.24034/i25485024.y2011.v15.i3.371 
Tella, R. D., \& Schargrodsky, E. (2014). The role of wages and auditing during a crackdown on corruption in the city of Buenos Aires. Chicago Journals, 46(1), 269-292. Retrieved from

https://www.hbs.edu/faculty/Publication \%20Files/The \%20Role $\% 20$ of $\% 20$ Wages $\% 20$ and $\% 20$ Auditing $\% 20$ Buenos $\% 20$ Aires 73092 d4c-baf3-4e44-8c1b7c7310e9d15b.pdf

Tempo. (2016). Kejaksaan negeri Marabahan telisik korupsi dana desa. Retrieved from Tempo. Available at https://nasional.tempo.co/read/794459/kejaksaan-negerimarabahan-telisik-korupsi-dana-desa

Transparency International. (2018). Corruption perceptions. Retrieved from Transparency International. Available at http://cpi.transparency.org/cpi2013/results/

Treisman, D. (2000). The causes of corruption: A cross-national study. Journal of Public Economics, 76(3), 399-457. https://doi.org/10.1016/S0047-2727(99)00092-4

Trompeter, G. M., Carpenter, T. D., Desai, N., Jones, K. L., \& Riley Jr., R. A. (2013). A synthesis of fraud-related research. Auditing: A Journal of Practice, 32(1), 287-321. https://doi.org/10.2308/ajpt-50360

Tuanakotta, T. M. (2010). Akuntansi forensik \& audit investigatif. Jakarta: Salemba Empat.

Van Rijckeghem, C., \& Weder, B. (2001). Bureaucratic corruption and the rate of temptation: Do wages in the civil service affect corruption, and by how much? Journal of Development Economics, 65(2), 307-331. https://doi.org/10.1016/S0304$\underline{3878(01) 00139-0}$

Vousinas, G. L. (2019). Advancing theory of fraud: the S.C.O.R.E. model. Journal of Financial Crime, 26(1), 372-381. https://doi.org/10.1108/JFC-12-2017-0128

Wang, J. (2018). Understanding Maslow's hierarchy of financial needs. Retrieved from Best Wallet Hacks. Available at https://wallethacks.com/maslows-hierarchy-of-financialneeds/

Yin, R. K. (2015). Studi kasus design \& metode. Jakarta: Rajawali Pers.

Yin, R. K. (2018). Case study research and applications: Design and methods. In SAGE Publications (Sixth Edit). SAGE Publications, Inc. 